\title{
ENERGY CONSUMPTION IN UNPUDDLED TRANSPLANTING OF WET SEASON RICE CULTIVATION IN NORTH WEST REGION OF BANGLADESH
}

\author{
AKM S. Islam*, M. M. Hossain'스, M. A. Saleque, M. A. Rabbani1 \\ and R. I. Sarker ${ }^{1}$ \\ Bangladesh Rice Research Institute, Gazipur, Bangladesh
}

\begin{abstract}
Unpuddled transplanting of rice is gaining attention in Bagnaldesh agriculture. Energy budget is essential for efficient management of the resources in agricultural production. The energy balance under different minimum tillage practices in rice cultivation was assessed during 2009-11 by comparing the parameters: energy input, energy output, energy productivity and energy output:input ratio. Energy input in CT, SPWT, BP and ST were 25.50, 23.15, 20.48 and $20.49 \mathrm{GJ}^{\mathrm{a}} \mathrm{a}^{-1}$ respectively in rice cultivation. Maximum energy was consumed for chemical fertilizers. Tillage energy ranked second in conventional tillage and ranked fourth in minimum tillage options. Energy output was insignificant due to insignificant yield difference. Unpuddled transplanting (BP and ST) showed 8-12\% increase in energy productivity and $22-24 \%$ increase in energy output:input ratio. However, from the energy saving point of view, unpuddled transplanting may be considered better options depending on the resources availability in rice cultivation.
\end{abstract}

Key Words: Minimum tillage, Direct energy, Indirect energy, Energy productivity, Energy ratio

\section{INTRODUCTION}

Effective energy use is one of the conditions for sustainable agricultural production, since it provides financial savings, fossil resources preservation and air pollution reduction (Uhlin, 1998). Productivity of agriculture depends on adequate inputs such as power (farm machines, human labour, animal draft, electrical), improved seeds, fertilizers and irrigation water. Crop yield is directly proportional to the energy input (Srivastava, 1982). In comparison to conventional cultivation with plough, the fuel consumption could be reduced for cultivation by 2 to 3 fold with a strip tillage system (Islam et al., 2012). Fuel and fertilizers $(\mathrm{N}$ and $\mathrm{P})$ account for the largest share $(>75 \%)$ of all energy expenditures in a mixed cropping system (Safa and Tabatabaeefar, 2002). Bockari-Gevao et al. (2005) reported that the highest average operational energy consumption was for tillage $\left(1.75 \mathrm{GJ} \mathrm{ha}^{-1}\right)$ which accounted for about $48.6 \%$ of the total operational energy consumption (3.6 GJ ha-1), followed by harvesting $\left(1.17 \mathrm{GJ} \mathrm{ha}^{-1}, 32.6 \%\right)$ and planting $\left(0.56 \mathrm{GJ} \mathrm{ha}^{-1}, 15.7 \%\right)$ in the lowland

\footnotetext{
1Department of Farm Power and Machinery, Bangladesh Agricultural University, Mymensingh-2202, Bangladesh

*Corresponding author (Email: akmsaiful68@yahoo.com)
} 
rice production system in Malaysia. The energy saving of 50\% and fuel saving of 30\% were achieved by site-specific tillage as compared to uniform-depth tillage in a loamy sand soil type (Alimardani et al., 2007). Due to increasing fuel prices, energy efficiency in crop production became an increasing awareness. Minimum tillage requires less total energy to achieve approximately the same crop production levels as conventional tillage systems (Smith et al., 2002). The energy and agriculture relationship is becoming more and more important with the intensification of the cropping systems. Energy budgets for agricultural production can be used as first step towards identifying crop production processes. The input elements need to be identified in order to prescribe the most efficient methods for controlling them. The benefits of energy analysis are to determine the energy invested in every step of the production process, to provide a basis for conservation and to aid in making sound management and policy decisions for efficient management of scarce resources for improved agricultural production. Rice establishment under unpuddle transplanting system is the new phenomenon and appeared as an emerging technology in rice cultivation. Islam et al. (2012) conducted an experiment to establish rice in unpuddled condition and got some exciting results on irrigation water saving and reduction of tillage and cost without grain yield penalty. No such information on the estimate of energy consumption in unpuddled transplating of rice is available. There is a need to estimate the energy consumption in unpuddled transplating of rice cultivation. Therefore, the present research was undertaken to expedite the energy involved in wet season transplanted rice culture under conventional puddling and a range of unpuddled systems.

\section{MATERIALS AND METHODS}

Three years trials was conducted at Rajshahi Regional Station, Bangladesh Rice Research Institute during 2009-2011. The experiment was laid out in a randomized block design with three replications (Gomez and Gomez, 1984). The tillage treatment involved conventional tillage (CT), single pass wet tillage (SPWT) as puddle transplating and bed planting (BP) and strip tillage (ST) as unpuddled transplanting. CT consisted of 2 passes primary tillage by two wheel tractors (2WT) and exposed to sun for two days followed by inundating whole plot and puddling by $2 \mathrm{WT}$ with 2 passes to complete land preparation. In SPWT, one pass tillage by 2WT after inundating the field. ST and BP were done by Versatile Multi-crop Planter (VMP) in single pass operation before inundating the field. The land was fully inundated one day before transplanting in unpuddled plots. Twenty five-day-old rice seedlings of BR 11 were transplanted in all treatments by hand. Seedlings were transplanted into puddled conditions (CT and SPWT) and unpuddled conditions (BP and ST). The inputs in the form of labour, diesel, seed, chemical fertilizer, plant protection products (insecticides/pesticides/herbicides) used in different stages of crop production and outputs obtained in terms of yield were taken into consideration by appropriate use of energy conversion factors as detailed in Table 1. The energy use was calculated for agronomic operations namely, (i) land preparation, (ii) puddling, (iii) seedling raising \& transplanting, (iv) interculture/weeding, (v) irrigation, (vi) crop management and (vii) harvesting and threshing. Energy input was also classified on the basis of source, whether it was direct and indirect. The direct energy input is the energy consumption of physical energy resources for physical work during field operations. Energy input such as human labor and fuel 
consumption have been considered as direct energy input. Indirect energy is the energy used to produce equipment and other goods and services that are used in the farm.

Table 1. Energy values used in energy calculation

\begin{tabular}{|c|c|c|c|}
\hline Particulars & Unit & $\begin{array}{l}\text { Energy equivalent } \\
\left(\mathrm{MJ} \text { unit }^{-1}\right)\end{array}$ & References \\
\hline \multicolumn{4}{|l|}{ A. Inputs } \\
\hline 1. Human labor & $\mathrm{h}$ & 0.2014 & Bala and Hussain, 1992 \\
\hline 2. Machinery & $\mathrm{h}$ & 62.7 & Erdal et al., 2007 \\
\hline 3. Diesel fuel & $\mathrm{L}$ & 56.31 & Erdal et al., 2007 \\
\hline 4. Chemical fertilizers & $\mathrm{kg}$ & & \\
\hline (a) Nitrogen (N) & & 66.14 & Esengun et al., 2007 \\
\hline (b) Phosphate $\left(\mathrm{P}_{2} \mathrm{O}_{5}\right)$ & & 12.44 & Esengun et al., 2007 \\
\hline (c) Potassium $\left(\mathrm{K}_{2} \mathrm{O}\right)$ & & 11.15 & Esengun et al., 2007 \\
\hline (d) Zinc (Zn) & & 8.40 & Argiro et al., 2006 \\
\hline \multirow{2}{*}{$\begin{array}{l}\text { a. Chemicals (granular) } \\
\text { b. Chemical (liquid) }\end{array}$} & $\mathrm{kg}$ & 120 & Canakci et al., 2005 \\
\hline & $\mathrm{ml}$ & 0.102 & Gopalan et al., 1978 \\
\hline 6. Water for irrigation & $\mathrm{m}^{3}$ & 1.02 & Acaroglu and Aksoy, 2005 \\
\hline 7. Seed & $\mathrm{kg}$ & 14.57 & Bala and Hussain,1992 \\
\hline \multicolumn{4}{|l|}{ B. Outputs } \\
\hline 1. Grain & $\mathrm{kg}$ & 14.57 & Bala and Hussain, 1992 \\
\hline 2. Straw & $\mathrm{kg}$ & 12.50 & Ozkan et al., 2004 \\
\hline
\end{tabular}

\section{Computation of energy inputs, outputs, productivity and ratio}

The energy input, output, output:input ratio as well as the energy productivity in rice cultivation were calculated based on the following formula as described in Chamsing et al., (2006).

\section{Energy input (Ei)}

Energy input (Ei), $\left(\mathrm{GJ} \mathrm{ha}^{-1}\right)=\mathrm{Ef}+\mathrm{Es}$

Where,

$\mathrm{Ef}=$ energy input in farm operations, $\mathrm{GJ} \mathrm{ha}^{-1}$

Es = energy sequestered of machinery, GJ ha-1

\section{Energy input in farm operations (Ef)}

Energy input in farm operation $\left(\mathrm{GJ} \mathrm{ha}^{-1}\right)=\mathrm{Phy}+\mathrm{Chem}+\mathrm{Bio}$

Where,

Phy $=$ Physical energy input in farm operation, GJ ha-1

Chem $=$ Chemical energy input in farm operation, GJ ha-1

Bio $=$ Biological energy input in farm operation, $\mathrm{GJ} \mathrm{ha}^{-1}$ 
Energy sequestered in mechanical power sources, (Es)

Energy sequestered in machinery was calculated using following formula.

Energy sequestered $\left(\mathrm{GJ} \mathrm{ha}^{-1}\right)=\mathrm{M} \times \mathrm{h}$

Where,

$M=$ Energy sequestered in manufacturing of machinery, $G J \mathrm{~h}^{-1}$

$\mathrm{h}=$ Machine working hour, $\mathrm{h}$ ha-1

\section{Energy output (Eo)}

Energy output was based on main product and by-product.

Energy output $\left(\mathrm{GJ}\right.$ ha $\left.^{-1}\right)=($ Yield $x$ Eeqm $)+($ By-product $x$ Eeqb $)$

Where,

Eeqm $=$ Energy equivalent value of main product

Eeqb $=$ Energy equivalent value of by-product

\section{Energy productivity (Ep)}

$$
\text { Energy productivity }\left(\mathrm{Kg} \mathrm{GJ}^{-1}\right)=\frac{\text { Crop yield, } \mathrm{Kg} \mathrm{ha}^{-1}}{\text { Energy inputs to crop production, } \mathrm{GJ} \mathrm{ha}^{-1}}
$$

Energy output-input ratio (Energy use efficiency)

$$
\text { Energy output-input ratio }=\frac{\text { Energy output, GJ ha-1 }}{\text { Energy inputs to crop production, GJ ha-1 }}
$$

\section{RESULTS AND DISCUSSION}

\section{Source-wise energy distribution}

Source wise energy distribution in rice cultivation under different tillage practices is given in Table 2. Direct energy included fuel and human labour. Direct energy consumption accounted for only a small proportion of the total energy consumption ranging from around $9-12 \%$ in CT, 6-7\% in SPWT, 8-9\% in BP and 4-7\% in ST. Direct energy was the highest in CT and the lowest in SPWT due to difference in fuel use. Fuel is the main contributor of direct energy with $8-11 \%$ in $\mathrm{CT}, 5-6 \%$ in SPWT, $7-8 \%$ in $\mathrm{BP}$ and $3-6 \%$ in ST. Indirect energy consumption included seed, machinery use, fertilizing, plant protection and irrigation. Indirect energy shared $88-91 \%$ in CT, $93-94 \%$ in SPWT, $91-92 \%$ in BP and $93-96 \%$ in ST. Indirect energy contributed maximum energy compared to direct energy in rice production. The largest source of indirect energy consumption was from fertilizer $9.93 \mathrm{GJ} \mathrm{ha}^{-1}$ (37 to 52 $\%$ of the total energy consumption). Seed energy was the highest in ST compared to other tillage operation. Machinery energy was the highest in CT followed by SPWT, BP and ST. Unpuddled transplanting (BP and ST) decreased direct fuel use and reduced indirect machinery use in rice cultivation. 
Table 2. Energy consumption (GJ ha-1) based on energy sources under different tillage options for rice cultivation

\begin{tabular}{|c|c|c|c|c|}
\hline Source & $\mathrm{CT}$ & SPWT & $\mathrm{BP}$ & ST \\
\hline \multicolumn{5}{|c|}{ Rice 2009} \\
\hline \multicolumn{5}{|l|}{ Direct energy } \\
\hline Fuel & $2.20(8)$ & $2.24(8)$ & $1.51(8)$ & $0.54(3)$ \\
\hline Human & $0.16(1)$ & $0.17(1)$ & $0.25(1)$ & $0.25(1)$ \\
\hline Subtotal & $2.35(9)$ & $2.41(9)$ & $1.76(9)$ & $0.78(4)$ \\
\hline \multicolumn{5}{|l|}{ Indirect energy } \\
\hline Seed & $0.44(2)$ & $0.44(2)$ & $0.44(2)$ & $0.58(3)$ \\
\hline Machinery & $4.39(16)$ & $3.89(15)$ & $1.01(5)$ & $0.60(3)$ \\
\hline Fertilizing & $9.93(37)$ & $9.93(38)$ & $9.93(49)$ & $9.93(52)$ \\
\hline Plant protection & $3.93(15)$ & $3.93(15)$ & $3.93(19)$ & $3.93(21)$ \\
\hline Irrigation & $5.71(21)$ & $5.71(22)$ & $3.21(16)$ & $3.28(17)$ \\
\hline Subtotal & $24.40(91)$ & $23.88(91)$ & $18.51(91)$ & $18.31(96)$ \\
\hline Total & $26.75(100)$ & $26.30(100)$ & $20.27(100)$ & $19.10(100)$ \\
\hline \multicolumn{5}{|c|}{ Rice 2010} \\
\hline \multicolumn{5}{|l|}{ Direct energy } \\
\hline Fuel & $2.06(8)$ & $0.99(5)$ & $1.33(7)$ & $1.08(5)$ \\
\hline Human & $0.21(1)$ & $0.24(1)$ & $0.23(1)$ & $0.24(1)$ \\
\hline Subtotal & $2.26(9)$ & $1.22(6)$ & $1.56(8)$ & $1.31(6)$ \\
\hline \multicolumn{5}{|l|}{ Indirect energy } \\
\hline Seed & $0.44(2)$ & $0.44(2)$ & $0.44(2)$ & $0.58(3)$ \\
\hline Machinery & $4.93(20)$ & $2.22(10)$ & $1.04(5)$ & $0.66(3)$ \\
\hline Fertilizing & $9.93(40)$ & $9.93(45)$ & $9.93(49)$ & $9.93(48)$ \\
\hline Plant protection & $3.93(16)$ & $3.93(18)$ & $3.93(19)$ & $3.93(19)$ \\
\hline Irrigation & $3.54(14)$ & $4.13(19)$ & 3.57 (17) & $4.38(21)$ \\
\hline Subtotal & $22.76(91)$ & $20.64(94)$ & $18.90(92)$ & $19.48(94)$ \\
\hline Total & $25.03(100)$ & $21.86(100)$ & $20.46(100)$ & $20.79(100)$ \\
\hline \multicolumn{5}{|c|}{ Rice 2011} \\
\hline \multicolumn{5}{|l|}{ Direct energy } \\
\hline Fuel & $2.81(11)$ & $1.27(6)$ & $1.53(7)$ & $1.38(6)$ \\
\hline Human & $0.17(1)$ & $0.20(1)$ & $0.20(1)$ & $0.20(1)$ \\
\hline Subtotal & $2.98(12)$ & 1.47 (7) & $1.73(8)$ & $1.58(7)$ \\
\hline \multicolumn{5}{|l|}{ Indirect energy } \\
\hline Seed & $0.44(2)$ & $0.44(2)$ & $0.44(2)$ & $0.58(3)$ \\
\hline Machinery & $3.92(16)$ & $1.96(9)$ & $1.28(6)$ & $0.76(3)$ \\
\hline Fertilizing & $9.93(40)$ & $9.93(47)$ & $9.93(48)$ & $9.93(46)$ \\
\hline Plant protection & $4.38(18)$ & $4.38(21)$ & $4.38(21)$ & $4.38(21)$ \\
\hline Irrigation & $3.07(12)$ & $3.11(15)$ & $2.97(14)$ & $4.38(20)$ \\
\hline Subtotal & $21.73(88)$ & $19.82(93)$ & $18.99(92)$ & $20.02(93)$ \\
\hline Total & $24.71(100)$ & $21.30(100)$ & $20.72(100)$ & $21.60(100)$ \\
\hline
\end{tabular}




\section{Operation-wise energy distribution}

Operational energy was computed for the seedling raising, tillage, transplanting, weeding, fertilizing, spraying, harvesting and winnowing (Table 3). In puddled CT, energy associated with different operations are: fertilizer $37-40 \%$, tillage $25-28 \%$, irrigation $12-21 \%$ and plant protection $15-18 \%$ of total energy consumption. Fertilizer ranked first and tillage ranked second as input energy in CT.

Table 3. Operation-wise energy input (GJ ha-1) under different tillage options for rice cultivation

\begin{tabular}{|c|c|c|c|c|}
\hline Operations & $\mathrm{CT}$ & SPWT & $\mathrm{BP}$ & ST \\
\hline \multicolumn{5}{|c|}{ Rice 09} \\
\hline Seedling raising & $0.45(2)$ & $0.45(2)$ & $0.45(2)$ & $0.60(3)$ \\
\hline Land preparation & $6.60(25)$ & $6.16(23)$ & $2.53(12)$ & $1.13(6)$ \\
\hline Transplanting and weeding & $0.08(0)$ & $0.08(0)$ & $0.18(1)$ & $0.18(1)$ \\
\hline Fertilizer application & $9.93(37)$ & $9.93(38)$ & $9.93(49)$ & $9.93(52)$ \\
\hline Plant protection & $3.93(15)$ & $3.93(15)$ & $3.93(19)$ & $3.93(21)$ \\
\hline Irrigation & $5.71(21)$ & $5.70(22)$ & $3.20(16)$ & $3.28(17)$ \\
\hline Harvesting and winnowing & $0.05(0)$ & $0.05(0)$ & $0.04(0)$ & $0.04(0)$ \\
\hline Total & 26.75a (100) & 26.29a (100) & $20.27 b(100)$ & $19.09 \mathrm{c}(100)$ \\
\hline \multicolumn{5}{|c|}{ Rice 10} \\
\hline Seedling raising & $0.45(2)$ & $0.45(2)$ & $0.45(2)$ & $0.60(3)$ \\
\hline Land preparation & $7.01(28)$ & $3.21(15)$ & $2.37(12)$ & $1.74(8)$ \\
\hline Transplanting and weeding & $0.12(0)$ & $0.16(1)$ & $0.16(1)$ & $0.16(1)$ \\
\hline Fertilizer application & $9.95(40)$ & $9.95(46)$ & $9.95(49)$ & $9.95(48)$ \\
\hline Plant protection & $3.93(16)$ & $3.93(18)$ & $3.93(19)$ & $3.93(19)$ \\
\hline Irrigation & $3.54(14)$ & $4.13(19)$ & $3.57(17)$ & $4.38(21)$ \\
\hline Harvesting and winnowing & $0.03(0)$ & $0.03(0)$ & $0.03(0)$ & $0.03(0)$ \\
\hline Total & 25.03a (100) & $21.86 b(100)$ & 20.46c (100) & $20.79 c(100)$ \\
\hline \multicolumn{5}{|c|}{ Rice 11} \\
\hline Seedling raising & $0.45(2)$ & $0.45(2)$ & $0.45(2)$ & $0.60(3)$ \\
\hline Land preparation & $6.74(27)$ & $3.25(15)$ & $2.81(14)$ & $2.13(10)$ \\
\hline Transplanting and weeding & $0.08(0)$ & $0.11(1)$ & $0.12(1)$ & $0.11(1)$ \\
\hline Fertilizer application & $9.94(40)$ & $9.94(47)$ & $9.94(48)$ & $9.94(46)$ \\
\hline Plant protection & $4.38(18)$ & $4.38(21)$ & $4.38(21)$ & $4.38(21)$ \\
\hline Irrigation & $3.07(12)$ & $3.11(15)$ & $2.97(14)$ & $4.38(20)$ \\
\hline Harvesting and winnowing & $0.05(0)$ & $0.05(0)$ & $0.05(0)$ & $0.05(0)$ \\
\hline Total & 24.71a (100) & 21.30c (100) & 20.72d (100) & $21.60 \mathrm{~b}(100)$ \\
\hline
\end{tabular}

Figures in the parenthesis indicate the percentage. In rice $09, \mathrm{LSD}_{0.05}=0.73, \mathrm{CV}(\%)=1.57$, in rice 10 , $\mathrm{LSD}_{0.05}=0.49, \mathrm{CV}(\%)=1.12$ and in rice $11 \mathrm{LSD}_{0.05}=0.13, \mathrm{CV}(\%)=0.30$ 
In unpuddled BP, energy associated with different operations was accounted as fertilizer $48-49 \%$, tillage $12-14 \%$, irrigation $15-19 \%$ and plant protection $19-21 \%$ of total energy consumption. Fertilizer ranked first and tillage ranked fourth as input energy in BP. Similar pattern was observed in puddled SPWT and unpuddled ST. Energy input for fertilizing represented the major part of total input energy (39-52\%) which was more than that of percentage energy utilized in fertilizing reported by Chaudhary et al. (2006) and Islam et al. (2001). Three years average data on rice cultivation showed that energy input was significantly highest in puddled transplanting than unpuddled transplanting (BP and ST). Energy input was the lowest in ST compared to BP due to the lowest land preparation energy whereas, irrigation energy was the highest in ST. SPWT, BP and ST saved 9\%, 20\%, and $20 \%$ energy input, respectively compared to CT. In this study, the lowest percentage of energy input occurred in the minimum tillage and the highest in CT. These findings supported the several investigations that the energy input for fuel consumption can be reduced with minimum tillage management (Franzluebbers and Francis, 1995; Borin et al., 1997) and that the highest energy use occurred with CT (Bailey et al., 2003).

\section{Energy output-input relationship}

Energy output-input relationship in rice cultivation is shown in Table 4. Energy gain was varied across the tillage treatment. Differences in energy input and equivalent yield resulted in a large variation of energy balance in wet land rice cultivation. Energy productivity was $8-12 \%$ higher in unpuddled transplanting (BP and ST) than puddled transplanting. Energy output-input ratio was found almost identical among SPWT, BP and ST. Energy outputinput ratio was the highest in third rice season due to increased yield in all tillage operation. Energy output:input ratio was the highest in unpuddled transplanting than puddled transplanting. Energy output:input ratio was higher by $15 \%, 22 \%$ and $24 \%$ in SPWT, BP and ST, respectively compared to CT. Energy output:input ratio tended to increase when soil tillage operations were reduced. This is in agreement with Borin et al. (1997). Many researchers reported that minimum tillage maximized the output:input ratio of crop production systems.

Table 4. Energy output-input relationship under different tillage options for rice cultivation

\begin{tabular}{c|c|c|c|c|c|c|c}
\hline \multirow{2}{*}{ Parameter } & Year & \multicolumn{7}{c}{ Tillage } & \multicolumn{2}{c}{} \\
\cline { 3 - 8 } & & CT & SPWT & BP & ST & CV (\%) & LSD $_{0.05}$ \\
\hline Energy & 2009 & 123 & 125 & 121 & 122 & 8.88 & NS \\
output & 2010 & 109 & 119 & 111 & 114 & 1.12 & 0.49 \\
$\left(\right.$ GJ ha $\left.^{-1}\right)$ & 2011 & 187 & 184 & 178 & 180 & 1.50 & NS \\
\cline { 2 - 8 } & Average & $\mathbf{1 3 9 . 7}$ & $\mathbf{1 4 2 . 7}$ & $\mathbf{1 3 6 . 7}$ & $\mathbf{1 3 8 . 7}$ & & \\
\hline Energy & 2009 & 170 & 170 & 220 & 230 & 5.80 & 30 \\
productivity & 2010 & 109 & 119 & 111 & 114 & 1.12 & 0.49 \\
(kg GJ-1) $^{-1}$ & 2011 & 187 & 184 & 178 & 180 & 1.50 & NS \\
\cline { 2 - 8 } & Average & $\mathbf{1 5 5 . 3}$ & $\mathbf{1 5 7 . 7}$ & $\mathbf{1 6 9 . 7}$ & $\mathbf{1 7 4 . 7}$ & & \\
\hline Energy ratio & 2009 & 4.6 & 4.8 & 6.0 & 6.5 & 8.70 & 0.95 \\
& 2010 & 4.4 & 5.5 & 5.5 & 5.5 & 6.91 & 0.72 \\
& 2011 & 7.6 & 8.6 & 8.6 & 8.4 & 1.77 & 0.3 \\
\cline { 2 - 7 } & Average & $\mathbf{5 . 5}$ & $\mathbf{6 . 3}$ & $\mathbf{6 . 7}$ & $\mathbf{6 . 8}$ & & \\
\hline
\end{tabular}




\section{CONCLUSION}

Unpuddled transplanting (BP and ST) saved 20\% energy input compared to CT in rice cultivation. Energy productivity and energy output:input ratio in unpuddled transplanting was $8-12 \%$ and $22-24 \%$ higher than conventional puddled. Bed planting and strip tillage were appeared as energy efficient in terms of energy costs and energy produced in rice cultivation.

\section{ACKNOWLEDGEMENTS}

This study was a part of the $\mathrm{PhD}$ research of the senior author. The authors are acknowledging the Bangladesh Agricultural Research Council for funding support from NATP-Phase 1.

\section{REFERENCES}

Acaroglu, M. and Aksoy, A. S. 2005. The cultivation and energy balance of Miscanthus_giganteus production in Turkey. Biomass Bioenergy, 29: 42-48.

Alimardani, R., Abbaspour-Gilandeh, Y., Khalilian, A., Keyhani, A. and Sadati, S. H. 2007. Energy savings with variable-depth tillage "A Precision Farming Practice" American-Eurasian J. Agric. $\mathcal{E}$ Environ. Sci., 2(4): 442-447.

Argiro, V., Strapatsa, A., George, D., Nanos, A. and Constantinos, A. 2006. Energy flow for integrated apple production in Greece. Agriculture, Ecosystems and Environment, 116: 176-180.

Bailey, A. P., Basford, W. D., Penlington, N., Park, J. R., Keatinge, J. D. H., Rehman, T., Tranter, R. B., and Yates, C. M. 2003. A comparison of energy use in conventional and integrated arable farming systems in the UK. Agric. Ecosyst. Env., 97: 241-253.

Bala, B. K. and Hussain, M. D. 1992. Energy use pattern for crop production in Bangladesh. Journal of Engineering for International Development, 1(3): 41-47.

Bockari-Gevao, S. M., Wan Ishak, W. I., Azmi, Y. and Chan, C. W. 2005. Analysis of energy consumption in lowland rice-based cropping system of Malaysia. Songklanakarin J. Sci. Technol., 27(4): 819-826.

Borin, M., Menini, C. and Sartori, L. 1997. Effect of tillage system on energy and carbon balance in north-eastern Italy. Soil and Tillage Res., 40: 209-226.

Canakci, M., Topakci, M., Akinci, I. and Ozmerzi, A. 2005. Energy use pattern of some field crops and vegetable production: case study for Antalya region, Turkey. Energy Convers Manage, 46: 655-66.

Chamsing, A., Salokhe, V. and Singh, G. 2006. Energy consumption analysis for selected crops in different regions of Thailand. Agric. Eng. Int., 6(13): 1-18.

Chaudhary, V., Gangwar, B. and Pandey, D. 2006. Auditing of Energy Use and Output of Different Cropping Systems in India. Agricultural Engineering International: the CIGR Ejournal. Manuscript EE 05001 Vol. VIII. June.

Erdal, G., Esengun, K., Erdal, H. and Gunduz, O. 2007. Energy use and economical analysis of sugar beet production in Tokat province of Turkey. Energy, 32: 35-41. 
Esengun, K., Gunduz, O. and Erdal, G. 2007. Input-output energy analysis in dry apricot production of Turkey. Energy Convers Manage, 48: 592-598.

Franzluebbers, A. J. and Francis, C. A. 1995. Energy output:input ratio of maize and sorghum management systems in eastern Nebraska. Agric. Ecosyst. Env., 53: 271-278.

Gomez, K. A. and Gomez, A. A. 1984. Statistical Procedures in Agricultural Research, New York, Chichester, etc.: Wiley, $2^{\text {nd }}$ edn, pp. 680.

Gopalan, C., Sastri, B. V. R. and Balasubramaniam, S. C. 1978. Nutritive Value of Indian Foods. National Institute of Nutrition, ICMR, Hyderabad.

Islam, AKM S., Hossain, M. M., Saleque, M. A., Rahman, M. A., Karmakar, B. and Haque, M. E. 2012. Effect of minimum tillage soil properties, crop growth and yield of aman rice in drought prones northwest Bangladesh. Bangladesh Agron. J., 15(1): 43-51.

Islam, AKM S., Rahman, M. A., Ahiduzzaman, M. and Baqui, M. A. 2001. Energy audit for rice production under power tiller and bullock farming systems in Bangladesh. Online Journal of Biological Science, 1(9): 873-876.

Ozkan, B., Akcaoz, H. and Fert, C. 2004. Energy input-output analysis in Turkish agriculture. Renew Energy, 29: 39-51.

Safa, M. and Tabatabaeefar, A. 2002. Energy Consumption in Wheat Production in Irrigated and Dry Land Farming. In: Proc. Intl. Agric. Engg. Conf., Wuxi, China, Nov., 28-30, 2002.

Smith, J. A., Wilson, R. G., Binford, G. D. and Yonsts, C. D. 2002. Modeling for Soil Tillage, Irrigation and Fertilization Effects in Cotton Crops'. Applied Engineering in Agriculture, 18(3): 269-276.

Srivastava, A. C. 1982. A Comparative Study of Conventional and Mechanized Farming Relative to Energy Use and Cost. AMA. Spring 1982. pp. 42-46.

Uhlin, H. 1998. Why energy productivity is increasing: an I-O analysis of Swedish agriculture. Agric Syst., 56(4): 443-65. 